\title{
Climate and Water Balance Changes in the Kinneret Watershed: A Review
}

\author{
Moshe Gophen \\ Migal, Kiryat Shmone, Israel \\ Email: Gophen@Migal.org.il
}

How to cite this paper: Gophen, M. (2020) Climate and Water Balance Changes in the Kinneret Watershed: A Review. Open Journal of Modern Hydrology, 10, 21-29. https://doi.org/10.4236/ojmh.2020.102002

Received: February 21, 2020

Accepted: April 5, 2020

Published: April 8, 2020

Copyright ( 2020 by author(s) and Scientific Research Publishing Inc. This work is licensed under the Creative Commons Attribution International License (CC BY 4.0).

http://creativecommons.org/licenses/by/4.0/

\section{(c) (i) Open Access}

\begin{abstract}
Regional Climate Change studied during 1950-2019 aimed at enhancement of aridity was indicated recently in the Lake Kinneret (Israel) watershed. Climate change was indicated by: Higher periodical frequency of negative SPI Values (Standard Precipitation Index), decline of Precipitation regime and River flow inputs that was followed by decline of Lake Kinneret WL and Elevation of ET regime. Nevertheless aridity enhanced the opposite, decline of ET capacities. Underground flows indicated outputs enhancement. The temporal decline of air temperature during 1940-1980 probably due to the change of ALBEDO Factor was twisted later into regional temperature elevation. During the 1950s, old lake Hula and surrounding wetlands were drained and water cover surface was converted to plant cover, which enhanced sunlight energy reflection. Followed eventual climate change, management legislations were a reduction of water allocation for agricultural irrigation. A recent public dispute has indicated contradicted conclusions as causation for WL decline in Lake Kinneret: 1) Enhancement of Agricultural water consumption in the Upper Jordan Watershed and 2) Climate change-aridity enhancement. This paper confirms the second conclusion.
\end{abstract}

\section{Keywords}

Kinneret, Hula, Watershed, Climate Change, Water Balance, Agriculture

\section{Introduction}

The water balance of the watershed of Lake Kinneret and its consequent water level were significantly affected recently as a result of climate change resulting in 5 years in a row of severe drought. Consequently, a called for severe limitation of agricultural water allocation and consumption in the watershed were implemented aimed at protection of lake inflow capacities. Documented climate change conditions in the Hula Valley and in Lake Kinneret include: decline of precipita- 
tion (Figure 1) and consequently the Headwaters yields and decline of Water level in lake Kinneret was therefore recorded (Figure 2); air temperature increase (Figure 3; from 1985 by $1^{\circ} \mathrm{C}$ ) in the watershed and of lake water of $1.2^{\circ} \mathrm{C}$ and $2.0^{\circ} \mathrm{C}$ respectively; lowering of the Ground Water Table (GWT) in the Hula Valley; reduction of nutrient transportation by river inflows (concentrations and mass) into Lake Kinneret due to the decline of discharges; Water allocation and agricultural usage in the Kinneret watershed significantly reduced; It is suggested that the Kinneret WL decline is likely to be the result of climate change, and water scarcity but not to enhancement of agricultural farming consumption.

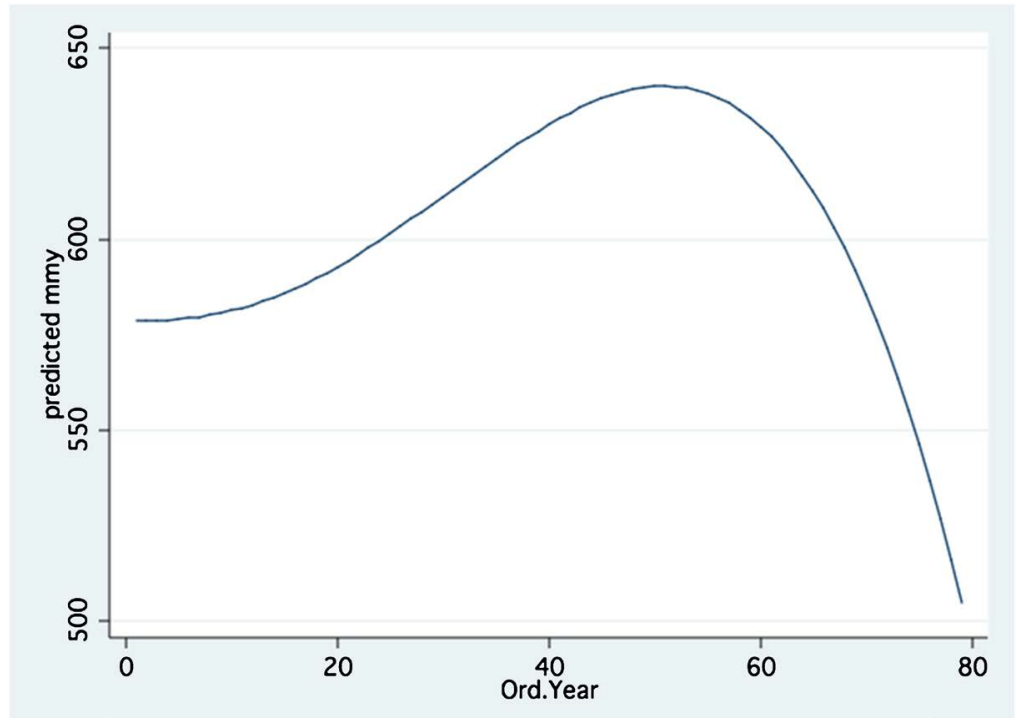

Figure 1. Fractional Polynomial regression between annual (1940-2018) precipitation and years $(0=1940 ; 80=2020)$.

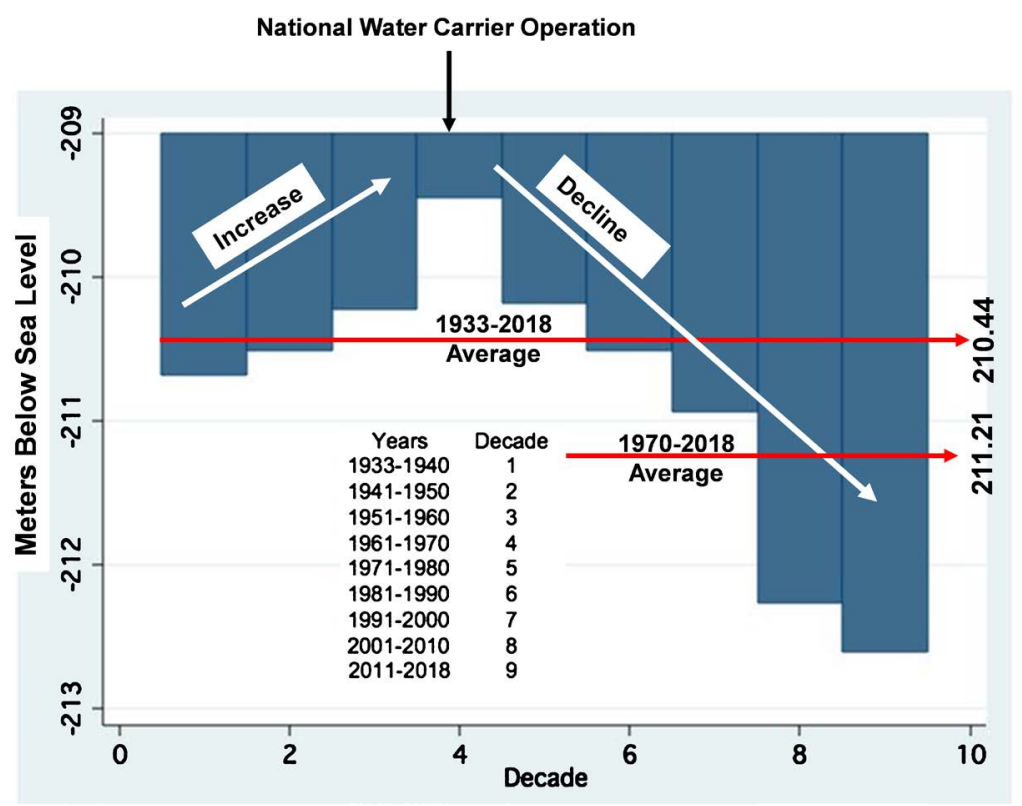

Figure 2. Ten year averages (1933-2018) of daily water level measures in Lake Kinneret White arrows indicate trend of changes; Red arrows indicate temporal means. 

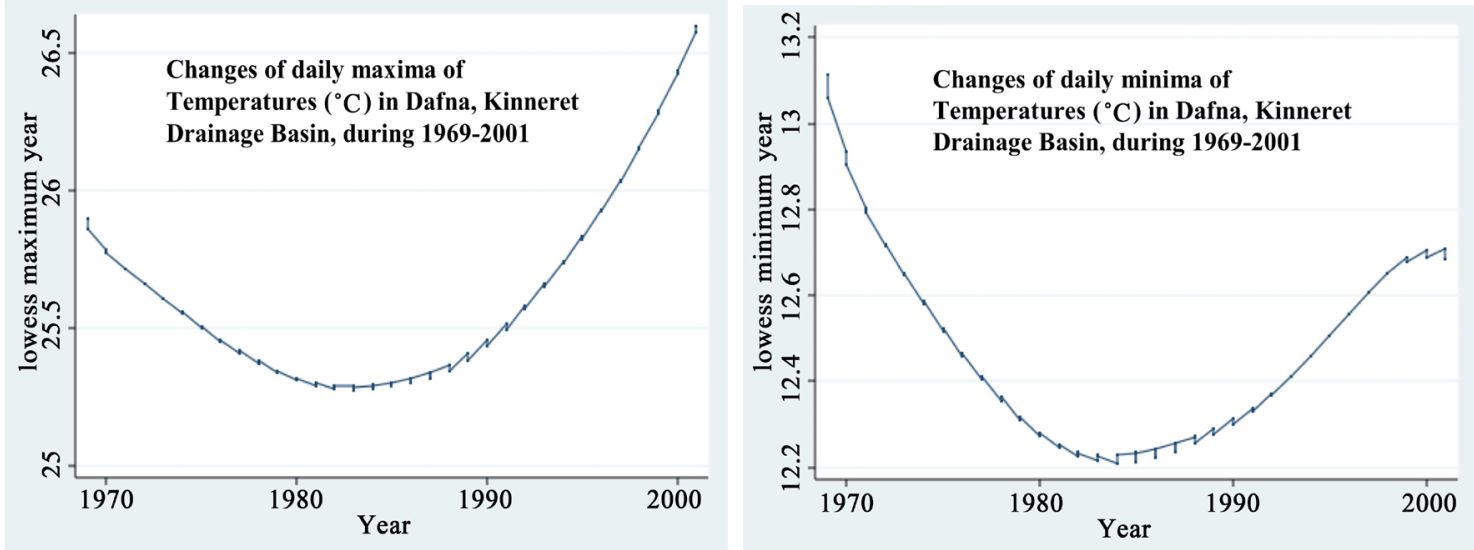

Figure 3. Trend of Changes (LOWESS; 0.8) of daily maxima (left panel) and minima (right panel) of air temperature $\left({ }^{\circ} \mathrm{C}\right)$ Dafna Station (Northern Hula Valley) during 1969-2001.

Agricultural development in the Upper Jordan River Watershed ("Upper Galilee") was initiated more than 100 years ago. Water supply for agricultural maintenance was all along the history of the regional settlement major national concern. Three major headwaters, Banias, Dan and Hatzbani, gushing northern to the lake, in the Hermon Mountain region combined into one Jordan River which crosses the Hula Valley through a split between two channels and further flow downstream southerly in unified one route. The ecological services of the Kinneret watershed and the Lake ecosystems are aimed at multiple purposes. Kinneret is the only natural freshwater lake in Israel located between latitudes of $32^{\circ} 42^{\prime} 15^{\prime \prime}$ and $32^{\circ} 53^{\prime} 44^{\prime \prime}$ North and the longitudes of $35^{\circ} 30^{\prime} 52^{\prime \prime}$ and $35^{\circ} 38^{\prime} 55^{\prime \prime}$ East. The Kinneret watershed is located between latitudes of $32^{\circ} 40^{\prime}$ and $33^{\circ} 38^{\prime}$ North. The total area of the Kinneret drainage basin is $2730 \mathrm{~km}^{2}$ of which $63 \%$ is an Israeli territory. The environmental trait and water quality protection of Lake Kinneret and its watershed is essential. Water sufficiency is crucial for the achievement of the ecosystem services. Moreover, water sharing between potential consumers is crucial and thoroughly precaution nationally and internationally guaranteed. When water availability resulted by normal-regular rainfall regime is sufficient, difficulties in water sharing are negligible whilst this task becomes disputable and tough under drought conditions. The present survey is aimed at the understanding of the reasons for WL decline in Lake Kinneret: Climate Change or agricultural consumption. Backward study is required for future design of lake water supply. The evaluation of rational concept for management during drought conditions is presently highly required.

\section{The Hula Valley Anthropocene Periodical Trait}

During the last 80 years, Lake Kinneret $\left(168 \mathrm{~km}^{2}\right)$ and its Drainage Basin $(2730$ $\mathrm{km}^{2}$ ) ecosystems have undergone significant anthropogenic and natural modifications. Conversion from wetland/old lake ecosystems (6900/1300 ha respectively) (1950-1957) to agriculture development. During the followed 40 years, the area 
was successfully cultivated, agricultural products were economically produced, and the nutrient flux into Lake Kinneret did not threaten its water quality. Inappropriate irrigation and cultivation methods, resulted peat soil quality deterioration consolidation, surface subsidence and destruction. Heavy dust storms, blocking of drainage canals, enhancement of underground fires, and outbreaks of rodent populations causing severe damage to agricultural crops. The density and volume capacity of preferential pathways in the undergrounds was enhanced and free space for subterranean accumulation of gravitating infiltration of running water increased. Moreover, 500 ha of the most deteriorated soil was ignored and abandoned. In order to prevent further soil deterioration and to ensure Lake Kinneret water quality protection a reclamation project (Hula Reclamation Project, HRP, 1993-2005) was implemented.

This project, was aimed at Kinneret water quality protection and agricultural improvements while retaining the economic utilization of this part of the Kinneret Drainage. The shift from conventional agriculture to eco-tourism was implemented on the most deteriorated part. The HPR objectives were: 1) Nutrients removal from the Lake Kinneret loads; 2) Creating ecological attraction for eco-tourism; 3) improvement of the water supply and drainage net line canals system; 4) Maintenance of high underground water table and additional water allocation ensuring peat soil moisture increase to prevent its deterioration; and 5) Increasing diversity of the re-establishment natural flora and fauna. The HRP program included: Construction of a new shallow lake Agmon (surface area of 110 ha, mean depth $-0.45 \mathrm{~m}$., volume $-0.44 \times 10^{6} \mathrm{~m}^{3}$ ), renewal of $90 \mathrm{~km}$ drainage and water supply canals, placing a vertical plastic barrier along $2.8 \mathrm{~km}$ crossing the valley from east to west, maintenance of higher underground water table (Figure 4).

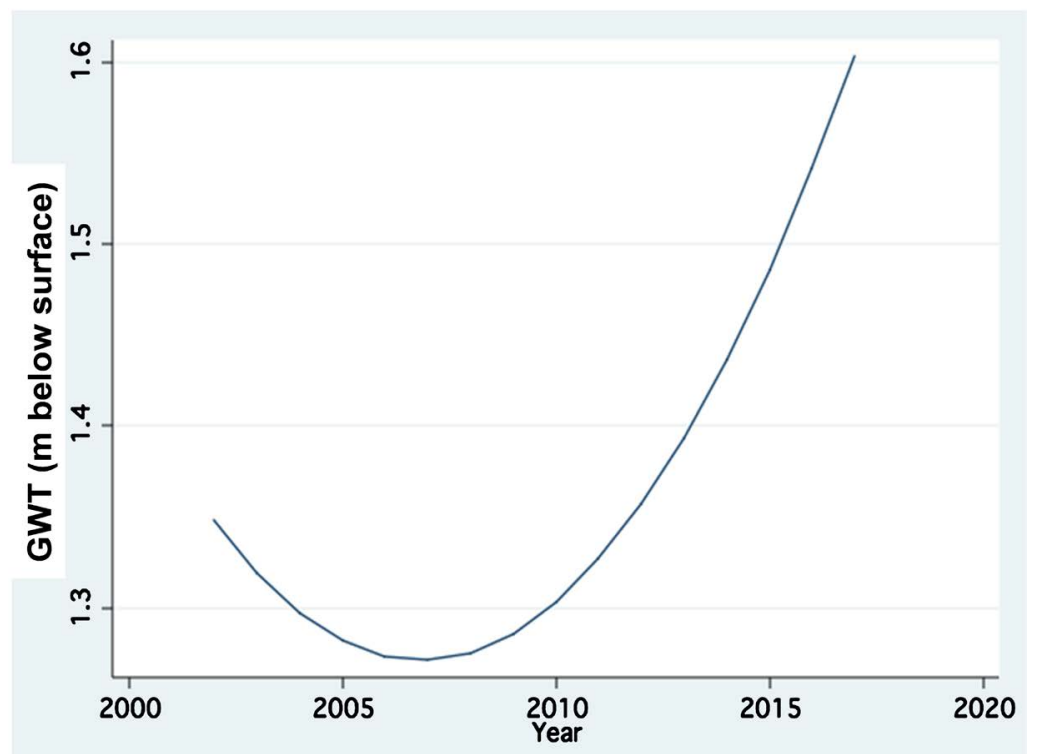

Figure 4. Annual Total (three Hula Valley regions) Average of GWT (m below surface) during 2002-2018. 
Prior to the Hula Valley drainage Nitrogen was fluxed into the lake, mostly as highly bio-available Ammonia, but after drainage the dominant $\mathrm{N}$-species were Nitrate and organic Nitrogen. Before mid-1990's, a daily volume of $25 \times 10^{3} \mathrm{~m}^{3}$ of Nitrogen rich raw sewage and fishpond (1700 ha) effluents, fluxed into lake Kinneret. The fishpond area was dramatically reduced to 350 ha, eliminating their effluents from the Kinneret loads. Raw sewage was removed from the lake and stored in reservoirs for reuse.

Significant impacts of recent developments on the Kinneret ecosystem were indicated: 1) Renovation of the national policy of water supply by construction of sea water desalinization Plants with total capacity of $650 \mathrm{mcm} / \mathrm{y}$ (annually $10^{6} \mathrm{~m}^{3}$ ) supporting $>95 \%$ of the national demands for domestic supply. The background was long term decline of lake WL and increase of domestic supply demands which also resulted restriction of agricultural water allocation in the catchment; and 2) Climate change causation of dryness enhancement (Figure 1) peaked as 5 years in a row (2013-2017) of extreme drought. The Anthropogenic intervention in the Hula Valley-Lake Kinneret ecosystem structures was aimed at improvement of human welfare resulted by water scarcity.

\section{The Climate Changed Challenge}

A steep decline (47\% of long term average in 2014) of precipitations in northern Israel [1] [2] [3] was documented. Historical lowest discharges of Dan $\left(2.67 \mathrm{~m}^{3} / \mathrm{s}\right)$ and Banias $\left(0.156 \mathrm{~m}^{3} / \mathrm{s}\right.$ ) headwaters were recorded in 2014 (HIS 1970-2017). Annual precipitations decline of $246 \mathrm{~mm}(6.2 \mathrm{~mm} / \mathrm{y})$ on the Golan Heights was documented during 1970-2010 resulting in a Kinneret budget decline. This decline of available water was approximately attributed mostly (73\%) to climatological dryness impact and the minority (27\%) to enhancement of consumption. Gophen (2018) suggested $38 \mathrm{mcm} / \mathrm{y}$ water loss during periodical drought by infiltration into subterranean free space in the Hula Valley [4].

Annual yields of the Kinneret headwaters were fairly stable with normal and seasonal (summer-winter) fluctuations until 2014 when the recent 5-years drought decline started [1]. A total decline of $77 \mathrm{mcm} / \mathrm{y}$ of the two major headwaters yield, Dan and Banias, was recorded and obviously the Jordan discharge. It is therefore suggested that water deficiency in the Kinneret Budget causing WL decline was mostly due to climate change. The assumptions about agricultural water consumption as the major parameter which is responsible for WL decline [5] can not be therefore confirmed. The monitored record of water consumption confirms decline of agricultural consumption whilst Lanset Imaginary evaluation (NDVI) [5] documented an opposite result.

IHS [1] and Givati [2] documented an increase of $40 \mathrm{mcm} / \mathrm{y}$ of water consumption until 2014 and precipitation decline of $110 \mathrm{mcm} / \mathrm{y}$ in the drainage basin: total reduction of available waters in Lake Kinneret was therefore $150 \mathrm{mcm} / \mathrm{y}$ during 1975-2014. Rimmer et al. [6] documented $200 \mathrm{mcm} / \mathrm{y}$ as total decline of available waters in the Lake Kinneret-Jordan ecosystem during 1967-2008, Water 
legislative allocation by the "National Water Authority" was significantly reduced from $>100$ during early 2000's to $75 \mathrm{mcm} / \mathrm{y}$ in 2018 Moreover, actual recorded agricultural utilization [1] by local consumers was: Golan Hight and Upper Galilee farming consumption-22.3 and $16.6 \mathrm{mcm} / \mathrm{y}$ during 2017 and 2018 respectively. Additional minor elimination $\left(14-17 \times 10^{6} \mathrm{~m}^{3}\right)$ from the Kinneret Budget is also pumped ("Zemer" and "Ayun" projects) from the crossing Hula Valley Western Canal to irrigate crops on the Dalton Plateau (Western part of the Upper Galilee). Conclusively, the climate change impact of dryness trend and the resulted decline of available water to the lake were in accordance. Moreover, an averaged measure of $>30 \mathrm{~cm}$ decline of GWT in the entire Hula Valley was recorded from 2007 and onwards (Figure 4).

The capacity of water transportation by the irrigation system (pipes, canals, etc) is not suitable for the transfer of $178 \mathrm{mcm} / \mathrm{y}$ [5] or $200 \mathrm{mcm} / \mathrm{y}$ [6] during the 3 - 5 months irrigation season. Moreover, information presented by the $\mathrm{Na}$ tional Water Authority confirmed restriction of water allocation from 120 before 2015, 85 from 2015 and $75 \mathrm{mcm} / \mathrm{y}$ in 2017. Therefore, climate change inducing precipitation and headwaters yields decline accompanied by restricted allocation was the optimal response.as appropriate management achievement. Complete prevention of Lake Kinneret WL decline was impossible.

The Impact of Vegetation Cover (Table 1)

The entire Hula Valley is mostly plant (agricultural crops) covered with seasonal exceptions since late 1950 's of which 4800 ha are presently tree covered (groves). The 74,500 ha of the entire Golan Heights area are tree covered (grove and vineyard). Total tree covered area of the Upper Jordan Watershed Upstream during 2017 is about 12,300 ha. The decline of soil surface temperature which is attributed to plant (trees and grass) cover which probably reduce ET was widely documented [7] [8] [9] [10] [11]. Landsat Imaginary analysis indicated an annual Evapo-transpiration of $849 \mathrm{~mm}$ for 2015 [5]. Hula Project Monitor Service documented 1376 and $1401 \mathrm{~mm} /$ year as annual [12] and 10 years average ( $\pm 10 \%)$ respectively [12]. The Hula Project Monitor Service record is based on Penman-Monteith Equation where Climatological parameters are incorporated. It is likely that the outcome of this discrepancy is probablly reflecting lower adequacy

Table 1. Land use policy $\left(\mathrm{km}^{2}\right)$ in the Kinneret Watershed.

\begin{tabular}{cc}
\hline Type of Land Cover & Area $\left(\mathrm{km}^{2)}\right.$ \\
\hline Field Crops & 180 \\
Orchards & 197 \\
Fishponds, reservoirs, Lake Agmon, Lake Kinneret & 171 \\
Natural Forest and Grove & 266 \\
Not Cultivated land & 1067 \\
Other & 111 \\
Total & 1992 \\
\hline
\end{tabular}


of the Landsat-Imaginary methodological analysis of water loss. The evaluation of water balance that is based on solid record has a higher credibility in this case. Multi-annual record (1960-2018) indicates no significant change in the vegetation cover in the Hula Valley region except seasonality of crop cycling. The ET capacities were, therefore, potentially stable more or less unless climate conditions changed. That is because ET records in the Hula Valley (Hula Project-Migal Data Base) are mostly climatologically dependant (Penman-Montheith formula). The headwaters yields are precisely monitored and carefully checked-up by the National Water Authority [1]. Water consumption in the Hula Valley, as assessed by Landsat imaginary analysis, is unequivocally lower than the IHS monitored reports resulting in a higher indication of anthropogenic consumption [5].

After the Hula drainage very minor changes of agricultural development (i.e. vegetation coverage) have been done, in the Hula Valley. The only significant modification of land use was a restriction of Fish Ponds from 1700 to 350 ha which indicates reduction of ET capacities because evaporated water loss from the free water surface is lower than that from soil surface.

Water supply for Irrigation on the Golan Heights is precipitation-dependant. Thirty-two reservoirs (total capacity $34 \mathrm{mcm} ; 10^{6} \mathrm{~m}^{3}$ ) were constructed on the Golan Heights to store natural runoff waters. Therefore, the maximum potential of water elimination from the Kinneret budget is $34 \mathrm{mcm} / \mathrm{y}$. The outcome of extreme drought resulting in empty reservoirs on the Golan Heights, then, a maximum of $19 \mathrm{mcm} / \mathrm{y}$ is guaranteed by the Water Authority to be supplied directly from the lake for agricultural irrigation on the Golan. Elimination of 34 $\mathrm{mcm}$ from the Lake Kinneret Budget is equivalent to $20 \mathrm{~cm}$ of WL. Moreover, maximum storage in the Golan reservoirs occurs when regional precipitation is surplus while all other resources are plentiful and Kinneret WL is increasing anyhow.

The evaluation of vegetation cover achieved by Landsat derived NDVI (Normalized Difference Vegetation Index) imagery are slightly misleading if solid data record of field measurements is available. Agricultural vegetation coverage, and, its water demands and ET capacities are known and measured. NDVI values are relevant if field data is not available. In the Kinneret Drainage basin a detailed long term data records of water allocation and consumption and agricultural vegetation coverage are available.

The Kinneret water balance management reflect an optimization between independent parameters of natural conditions (precipitations and river discharge) and dependant parameters, of anthropogenic constrains (demands for agriculture and domestic supply). Nevertheless, the Kinneret case has a wider significance than regional management. The significance of the ecological services of Lake Kinneret are both, regional and national. The lake water level is affected by both natural and anthropogenic parameters. The management design and the operational implementation are therefore representing the optimal acceptable compromise between Climate Change and anthropogenic consumption. Because 
independent climate change is the primary control the flexibility of the resulted operation is therefore ultimately required. The long term national water supply from lake Kinneret smoothly continued not without constrained pressures during short term droughts until the drought of 2013-2017 when a desalinization solution was implemented. As of today, agriculture in the Golan and Galilee flourished, and the lake was not devastated.

Evaluation of periodical drought case and their frequency as SPI (Standard Precipitation Index) values during 1930-2016 [2] indicated 13 and 17 years of severe drought during 1930-1970 and 1970-2016, respectively. Moreover, documentation of 20 meters (197 - 217 mbsl) WL changes in Lake Kinneret during 9000 [13] [14] years did not threaten its long-term ecological existence.

\section{Conclusions}

Lake ecosystem services priorities for Lake Kinneret comprised of the followings: top priority is given to domestic water supply, and lower priorities are given to fishery, tourism, recreation and nature protection. The Israeli full control of the Lake Kinneret water budget did not prevent water supply to the Palestinians in the West Bank and to the Jordan State. Hydro-Political water sharing treaties committed partial water sharing with neighbor countries and sufficiency of water supply to riparian countries within the natural sources. The protection of Lake Kinneret existence is achieved without interference accompanied by temporary adaptations to climate change constrains. Insufficient replenishment of the Kinneret storage capacity and lower WL was affected by reduction of water inputs which is due mostly to climate change [15].

Ironically, after a five years sequence drught corresponded with a dramatic lake WL decline the recent two seasons were heavy precipitation regime followed by exceptional WL increase with predicted south Dam open outcome. Conclusively, precipitation regime is (at least partly) unpredictable.

\section{Conflicts of Interest}

The author declares no conflicts of interest regarding the publication of this paper.

\section{References}

[1] The Israeli Hydrological Service (1970-2017) National Water Authority, Annual Reports 1970-2017.

[2] Givati, A. (2016) The Impact of Climate Changes on Water Resources in the North, Water Authority. PDF Presentation. (In Hebrew)

[3] Givati, A. and Rosenfeld, D. (2013) The Arctic Oscillation Climate Change and the Effect on Precipitation in Israel. Atmospheric Research, 132, 114-124. https://doi.org/10.1016/j.atmosres.2013.05.001

[4] Gophen, M. (2018) Climate Change and Water Loss in the Kinneret Drainage Basin. Land Use Policy, 80, 424-429. https://doi.org/10.1016/j.landusepol.2018.03.008 
[5] Wine, M.L., Rimmer, A. and Laronne, J. (2019) Agriculture, Diversions, and Drought Shrinking Galilee Sea. Science of the Total Environment, 651, 70-83. https://doi.org/10.1016/j.scitotenv.2018.09.058

[6] Rimmer, A., Gal, G., Opher, T., Leschinsky, Y. and Yacobi, Y. (2011) Mechanisms Long-Term Variations in the Thermal Structure of Lake Kinneret. Limnology and Oceanography, 56, 974-988. https://doi.org/10.4319/lo.2011.56.3.0974

[7] Karakus, C.B. (2019) The Impact of Land Use/Land Cover (LULC) Changes on Land Surface Temperature in Sivas City Center and Its Surroundings and Assessment of Urban Heat Island. Asian-Pacific Journal of Atmospheric Sciences, 55, 669-684. https://doi.org/10.1007/s13143-019-00109-w

[8] Bokaie, M., Zarkesh, M.K., Arantesh, M.P. and Hosseini, A. (2016) Assessment of Urban Heat Island Based on the Relationship between Land Surface Temperature and Land Use/Land Cover in Tehran. Sustainable Cities and Society, 23, 94-104. https://doi.org/10.1016/j.scs.2016.03.009

[9] Chen, X.L., Zhao, H.M., Li, P.X. and Yin, Z.Y. (2006) Remote Sensing Image-Based Analysis of the Relationship between Urban Heat Island and Land Use/Land Cover Changes. Remote Sensing of Environment, 104, 103-146.

https://doi.org/10.1016/j.rse.2005.11.016

[10] Julien, Y., Sonrino, J.A. and Verhoef, W. (1006) Changes in Land Surface Temperatures and NDVI Values over Europe between 1982 and 1999. Remote Sensing of Environment, 103, 43-55. https://doi.org/10.1016/j.rse.2006.03.011

[11] Kaufmann, R.K., Zhou, L., Myneni, R.B., Tucker, C.J., Slayback, D., Shabanov, N.V. and Pinzon, J. (2003) The Effect of Vegetation on Surface Temperature a Statistical Analysis of NDVI and Climate Data. Geophysical Research Letters, 30, 2137. https://doi.org/10.1029/2003GL018251

[12] Tsipris, J., Meron, M. and Orlov, V. (2005-2018) Evap-Transpiration Data in the Hula Valley: Migal, Hula Project Data Base.

[13] Hazan, D., et al. (2005) The Late Pleistocene-Holocene Limnological History of Lake Kinneret (Sea of Galilee). Quaternary Research, 63, 60-77. https://doi.org/10.1016/j.yqres.2004.09.004

[14] Vossel, H., et al. (2018) Lake Kinneret (Israel): New Insights into Holocene Regional Palaeoclimate Variability Based on High-Resolution Multi-Proxy Analysis. The Holocene, 28, 1395-1410. https://doi.org/10.1177/0959683618777071

[15] Tal, A. (2019) Lake Kinneret and Climate Change, 2019. Science of Total Environment, 664, 175-176. https://doi.org/10.1016/j.scitotenv.2019.01.371 